\title{
INVESTIGATION OF EXTRACELLULAR PROTEASE ACTIVITY OF TWO DIFFERENT EXTREMELY HALOPHILIC ARCHAEA ISOLATED FROM RAW HIDE
}

\author{
Fevziye Ișıl KESBiç ${ }^{1}$, Binnur MERiçLi YAPICI ${ }^{*}$ \\ ${ }^{1}$ Kastamonu University, Central Research Laboratory, Kastamonu-37100,Turkey, ikesbic@kastamonu.edu.tr \\ ${ }^{2}$ Çanakkale Onsekiz Mart University, Faculty of Arts and Sciences, Department of Biology, \\ Çanakkale-17020, Turkey, byapici@comu.edu.tr
}

https://doi.org/10.24264/Ifj.17.4.9

\section{INVESTIGATION OF EXTRACELLULAR PROTEASE ACTIVITY OF TWO DIFFERENT EXTREMELY HALOPHILIC ARCHAEA ISOLATED FROM RAW HIDE}

ABSTRACT. In this study, it was aimed to investigate extracellular protease activity of two different extremely halophilic archaea and to identify them by using phenotypic and molecular methods. The haloarchaea were isolated from salted raw hide. The isolates were screened for production of protease enzyme and two isolates which have extracellular protease activity were selected. To identify the halophilic archaea, Gram staining procedure, antibiotic sensitivity tests and molecular methods were used. According to the $16 \mathrm{~S} r$-RNA molecular identification results, isolate 1 identified as Halococcus morrhuae JCM 8876 with \% 99 sequence similarities and isolate 2 identified as Natrinema pallidum 153 with \% 99 sequence similarities. Azocasein was used as a substrate for measuring their proteases activities daily and their optimum activities were determined. H. morrhuae and N. pallidum showed daily maximum proteases activity on 6 and 4 days, respectively. According to the results of the study, it was found that proteases activity was related with different reaction conditions. These conditions were detected as different $\mathrm{pH}(4-11)$, temperature $\left(4-70^{\circ} \mathrm{C}\right)$ and $\mathrm{NaCl}$ concentration $(1-5 \mathrm{M})$ values. H. morrhuae showed the maximum activity at $\mathrm{pH} 9.5$, $2 \mathrm{M} \mathrm{NaCl}$ concentration and $50^{\circ} \mathrm{C}$ temperature and $\mathrm{N}$. pallidum displayed the optimum activity at $\mathrm{pH} 9.0,2 \mathrm{M} \mathrm{NaCl}$ concentration and $40^{\circ} \mathrm{C}$ temperature.

KEY WORDS: salted hide, haloarchaea, extracellular protease enzyme, 16S r-RNA sequence analysis.

INVESTIGAREA ACTIVITĂṬII PROTEAZICE EXTRACELULARE A DOUĂ ARCHAEA EXTREM HALOFILE DIFERITE IZOLATE DE PE PIELEA CRUDĂ REZUMAT. În acest studiu, s-a urmărit cercetarea activității proteazice extracelulare a două archaea extrem halofile diferite și identificarea acestora utilizând metode fenotipice și moleculare. Haloarchaea au fost izolate de pe pielea crudă sărată. Izolatele au fost evaluate în funcție de capacitatea de producere a enzimelor de tip protează și s-au selectat două izolate care au activitate proteazică extracelulară. Pentru a identifica archaea halofile, s-au utilizat proceduri de colorare Gram, teste de sensibilitate la antibiotice și metode moleculare. Conform rezultatelor identificării moleculare ARNr 16S, izolatul 1 a fost identificat ca Halococcus morrhuae JCM 8876 cu asemănări de secvență de 99\%, iar izolatul 2 a fost identificat ca Natrinema pallidum 153 cu asemănări de secvență de $99 \%$. S-a utilizat azocaseina ca substrat pentru măsurarea zilnică a activității proteazice și s-a determinat activitatea optimă a acestora. H. morrhuae și $N$. pallidum au prezentat activitate proteazică maximă zilnică la 6 , respectiv 4 zile. Conform rezultatelor studiului, s-a constatat că activitatea proteazică a fost corelată cu diferite condiții de reacție. Aceste condiții au constat în valori diferite ale pH-ului (4-11), ale temperaturii $\left(4-70^{\circ} \mathrm{C}\right)$ și ale concentrației de $\mathrm{NaCl}(1-5$ M). H. morrhuae a prezentat activitate maximă la pH 9,5, la concentrația de $\mathrm{NaCl}$ de $2 \mathrm{M}$ și la temperatura de $50^{\circ} \mathrm{C}$, iar $\mathrm{N}$. pallidum a prezentat activitate optimă la pH 9,0, concentrația de $\mathrm{NaCl}$ de $2 \mathrm{M}$ și temperatura de $40^{\circ} \mathrm{C}$.

CUVINTE CHEIE: piele sărată, haloarchaea, enzimă protează extracelulară, analiză de secvență ARNr 16S.

\section{ENQUÊTE SUR L'ACTIVITÉ PROTÉASE EXTRACELLULAIRE DE DEUX ARCHÉES DIFFÉRENTES EXTRÊMEMENT HALOPHILES ISOLÉES DE LA PEAU BRUTE}

RÉSUMÉ. Dans cette étude, l'objectif a été d'étudier l'activité protéase extracellulaire de deux archées différentes extrêmement halophiles et de les identifier en utilisant des méthodes phénotypiques et moléculaires. Les haloarchées ont été isolées de la peau brute salée. Les isolats ont été évalués selon la production d'enzyme protéase et deux isolats avec une activité protease extracellulaire ont été sélectionnés. Pour identifier les archées halophiles, une procédure de coloration de Gram, des tests de sensibilité aux antibiotiques et des méthodes moléculaires ont été utilisés. Selon les résultats d'identification moléculaire d'ARNr 16S, l'isolat 1 a été identifié comme Halococcus morrhuae JCM 8876 avec des similitudes de séquence de $99 \%$ et l'isolat 2 a été identifié comme Natrinema pallidum 153 avec des similitudes de séquence de $99 \%$. L'azocaséine a été utilisée comme substrat pour mesurer quotidiennement leurs activités protéases et leurs activités optimales ont été déterminées. $H$. morrhuae et $N$. pallidum ont montré une activité protéase maximale quotidienne à 6 et 4 jours, respectivement. Selon les résultats de l'étude, on a constaté que l'activité protéase a été liée à différentes conditions de réaction. Ces conditions ont été détectées avec différentes valeurs de $\mathrm{pH}(4-11)$, de température $\left(4-70^{\circ} \mathrm{C}\right)$ et de concentration de $\mathrm{NaCl}(1-5 \mathrm{M})$. H. morrhuae a montré une activité maximale à $\mathrm{pH} 9,5$, une concentration de $\mathrm{NaCl}$ de $2 \mathrm{M}$ et une température de $50^{\circ} \mathrm{C}$ et $\mathrm{N}$. pallidum a montré une activité optimale à pH 9,0, une concentration de $\mathrm{NaCl}$ de $2 \mathrm{M}$ et une température de $40^{\circ} \mathrm{C}$.

MOTS CLÉS: peau salée, haloarchées, enzyme protéase extracellulaire, analyse des séquences d’ARN-r 16S.

\footnotetext{
* Correspondence to: Binnur MERIÇLI YAPICI, Department of Biology, Faculty of Arts and Sciences, Çanakkale Onsekiz Mart University, 17020, Çanakkale,Turkey, byapici@comu.edu.tr
} 


\section{INTRODUCTION}

Microbial cells live in association with other cells in nature and populations of cell interact with other populations in microbial communities. The abundance and diversity of any microbial community is controlled by the resources available and conditions such as temperature, $\mathrm{pH}$, presence or absence of oxygen that prevail in that community [1]. A phylogenetic analysis based upon ribosomal RNA sequence characterization reveals that living systems represent three domains: the eubacteria, eukarya and archaea [2]. Archaea are the main group to thrive in extreme environments in terms of salinity, $\mathrm{pH}$ and temperature [3]. Halophilic archaea require 1.5-4 M NaCl for optimal growth and most of halophilic archaea can thrive up to the saturation point of $\mathrm{NaCl}$ around $5.5 \mathrm{M}$ [4]. Haloarcheae are found in habitats with high salinity such as salt and soda lakes, salted hides and fish [5]. Adaptations to extreme environments provide to serve in several of biotechnological and industrial applications [6]. Halophiles produce several biotechnological products. The most important of them are biopolymers, bacterio- and halorhodopsins, biosurfactants and enzymes $[7,8]$. Proteases are one of the most important groups of enzymes. Annual usage values of microbial proteases are determined as $25 \%$ for alkaline protease and $21 \%$ for other proteases. Halophilic proteases are used in the production of food, leather and detergent industry in particular [9]. Therefore, the aim of the present study was to investigate extracellular proteolytic activities of different halophilic archaea isolated from salted raw hide, to identify them phylogenetically and determine optimum and variable conditions such as $\mathrm{pH}$, concentration of $\mathrm{NaCl}$ and temperature.

\section{MATERIALS AND METHODS}

Two halophilic archaea which were isolated from salted raw hide were identified using Gram staining procedure, antibiotic sensitivity tests and 16S r-RNA sequence analysis. SW 25 medium was used for culture isolation, activation, growth and phenotypic tests. This medium was composed of 833.4 $\mathrm{ml} / \mathrm{I} \mathrm{SW} 30$ solution, $5 \mathrm{~g} / \mathrm{l}$ yeast extract, and $20 \mathrm{~g} / \mathrm{l}$ agar. SW 30 solution contained 234 $\mathrm{g} / \mathrm{l} \mathrm{NaCl}, 39 \mathrm{~g} / \mathrm{MgCl}_{2}, 61 \mathrm{~g} / \mathrm{l} \mathrm{MgSO}_{4}, 1 \mathrm{~g} / \mathrm{l}$ $\mathrm{CaCl}_{2}, 6 \mathrm{~g} / \mathrm{l} \mathrm{KCl}, 0.25 \mathrm{~g} / \mathrm{l} \mathrm{NaHCO}_{3}$ and $0.7 \mathrm{~g} / \mathrm{l}$ $\mathrm{NaBr}$. Media were adjusted to $\mathrm{pH} 7.5$ with $1 \mathrm{~N} \mathrm{NaOH}$. To detect Gram reactions and cell morphology of the isolates Gram staining was performed [10]. The disc diffusion method was used to determine antibiotic susceptibilities of the isolates with the following antibiotics: Novobiosin $30 \mu \mathrm{g}$ (NV30), Penicillin G 10 U (P10), Streptomycin $10 \mu \mathrm{g}$ (S10), Ampicillin $10 \mu \mathrm{g}$ (A10), Bacitracin $10 \mu \mathrm{g}$ (B10), Erythromycin $15 \mu \mathrm{g}$ (E15), Tetracycline $30 \mu \mathrm{g}$ (T30), Vancomycin $30 \mu \mathrm{g}$ (VAN30), Chloramphenicol $30 \mu \mathrm{g}$ (C30), and Cefotaxime $30 \mu \mathrm{g}$ (CTX30).

For genomic DNA isolation of isolates, commercial Bacterial DNA isolation kit was used and Dyall-Smith [11, 12] method was modified. The cultures grown in $250 \mathrm{ml}$ Erlenmeyer flasks containing $50 \mathrm{ml} \mathrm{SW}-25$ liquid medium were incubated at $40^{\circ} \mathrm{C}$ for 5 days at $150 \mathrm{rpm} .1 .5 \mathrm{ml}$ of samples $\left(\mathrm{OD}_{600}\right.$ 1) were taken and centrifuged at $10.000 \mathrm{~g}$ for 10 minutes at $+4^{\circ} \mathrm{C}$. The supernatants of the samples were removed and $400 \mu \mathrm{l}$ of sterile cold ultra pure water was added to the tubes to disintegrate the cells. The samples were centrifuged at $10,000 \mathrm{~g}$ for 3 minutes at $+4^{\circ} \mathrm{C}$ to remove supernatants and genomic DNA isolation was performed according to the instructions of the DNA isolation kit. Genomic DNAs were measured spectrophotometrically at absorbance values of $260 \mathrm{~nm}\left(\mathrm{~A}_{260}\right)$ and $280 \mathrm{~nm}\left(\mathrm{~A}_{280}\right)$. The purity grades of DNA were determined by $A_{260} /$ $A_{280}$ ratio and those between 1.5-1.8 were used for Polymerase Chain Reaction (PCR). To control the DNA bands, $0.8 \%$ agarose gel was prepared with 1X TAE. Syber ${ }^{\circledR}$ Green I and $6 \mathrm{X}$ gel loading dye were used for loading the samples into the agarose gel.

A commercial Taq DNA Polymerase kit was used for PCR setup protocol. The reaction was prepared in sterile $0.2 \mathrm{ml} \mathrm{PCR}$ tubes and the tubes were placed in the Thermal Cycler after brief centrifugation. At the end of the reaction, the PCR products were controlled 
on an $1.7 \%$ agarose gel. Chromatograms of sequence analyses were edited via Chromas and forward-reverse sequences were aligned on NCBI's (National Center of Biotechnology Information) website. The $16 \mathrm{~S}$ r-RNA gene regions of the isolates were analyzed by the nucleotide BLAST (Basic Local Alignment Search Tool) and compared with the 16S r-DNA sequences present in the GenBank database. A phylogenetic tree was constructed using the Mega program to establish the relationship between the isolates and their phylogenetically similar species.

For the determination of the protease production, skimmed-milk was added into the SW 25 medium. Clear zone observed around the colony was considered as positive protease activity. To product protease enzyme in shake flasks, $1 \mathrm{ml}$ of a week old culture of isolates was inoculated into a sterilized $250 \mathrm{~mL}$ Erlenmeyer flask containing $50 \mathrm{~mL}$ of the SW 25 medium and incubated at $40^{\circ} \mathrm{C}$ in an incubator shaker at $150 \mathrm{rpm} .1 \mathrm{~mL}$ of culture was taken on a daily basis and the contents were centrifuged at $10.000 \mathrm{~g}$ for 10 minutes to remove cells and insoluble materials. The cell free supernatant was used as the source of the crude enzyme $[13,14]$.

Proteolytic activity was determined using Azocasein solution as a substrate. The solution was composed $0.4 \%$ Azocasein, $2 \mathrm{M} \mathrm{NaCl}, 50 \mathrm{mM}$ Tris- $\mathrm{HCl}$ at $\mathrm{pH}$ 7.0. 500 $\mu \mathrm{l}$ of Azocasein substrate was incubated at $40^{\circ} \mathrm{C}$. After 10 minutes $100 \mu$ l enzyme was added to the reaction mixture and incubated at $40^{\circ} \mathrm{C}$ for 30 minutes. The reaction was stopped by the addition of $250 \mu \mathrm{l}$ of $\% 20$ TCA solution. The reaction mixture was centrifuged at $10.000 \mathrm{~g}$ for 10 minutes. $100 \mu \mathrm{l}$ of supernatant was taken and mixed with $900 \mu \mathrm{l} 2 \mathrm{M} \mathrm{NaOH}$ solutions. The enzyme activity was determined by measuring the absorbance at $440 \mathrm{~nm}$. The absorbance increase of 0.01 units at $440 \mathrm{~nm}$ in reaction conditions was determined as 1 unit $(U)$ activity $[15,16]$. Bacterial biomass was measured with VIS spectrophotometer (Mecasys Optizen Pop QX UVIVIS, Korea) at $600 \mathrm{~nm}[17,14]$. In the study the enzyme activities were measured daily.

The extracellular protease activities of two different archaea were monitored at different $\mathrm{pH}$ values $(\mathrm{pH} 4.0-11.0)$ at Azocasein substrate solutions with $\mathrm{NaOH}$, sodium acetate, and Tris- $\mathrm{HCl}$ buffer. The effect of temperature on the protease production was studied at different reaction temperature $\left(4-70^{\circ} \mathrm{C}\right)$. The other parameters were kept constant. The different $\mathrm{NaCl}$ concentrations (1.0-5.0M) were used in the Azocasein substrate to determine the optimum salinity.

\section{RESULTS AND DISCUSSION}

The haloarchaea isolated from salted raw hide were screened for production of protease enzyme. Two different isolates which have extracellular protease activity were selected. According to the gene bank database, it was found that isolate 1 was similar to Halococcus morrhuae JCM 8876 as 99\% and isolate 2 was similar to Natrinema pallidum 153 as 99\%, too. Phylogenetic tree based on 16S-rRNA sequence data indicating the relationship of isolates is shown in Figure 1.

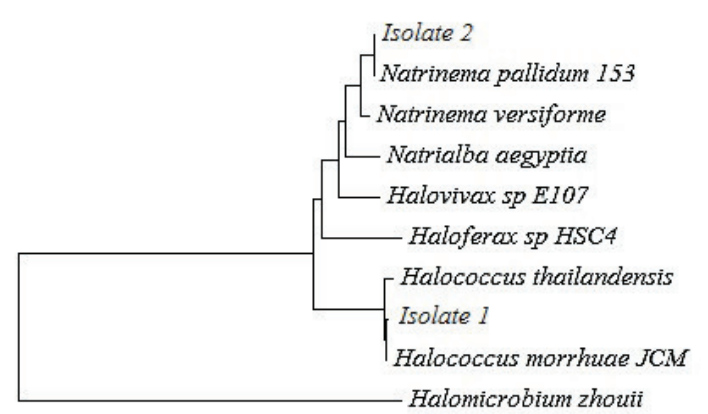

$$
\stackrel{5}{5}
$$

Figure 1. Phylogenetic tree based on 16S $r$-RNA sequence data indicating the relationship of isolates

Protease activities of isolates were 
measured daily. While the highest protease activity of Halococcus morrhuae was determined on the sixth day of growth (Figure 2), the maximum protease activity of Natrinema pallidum was observed on the fourth day (Figure 3).

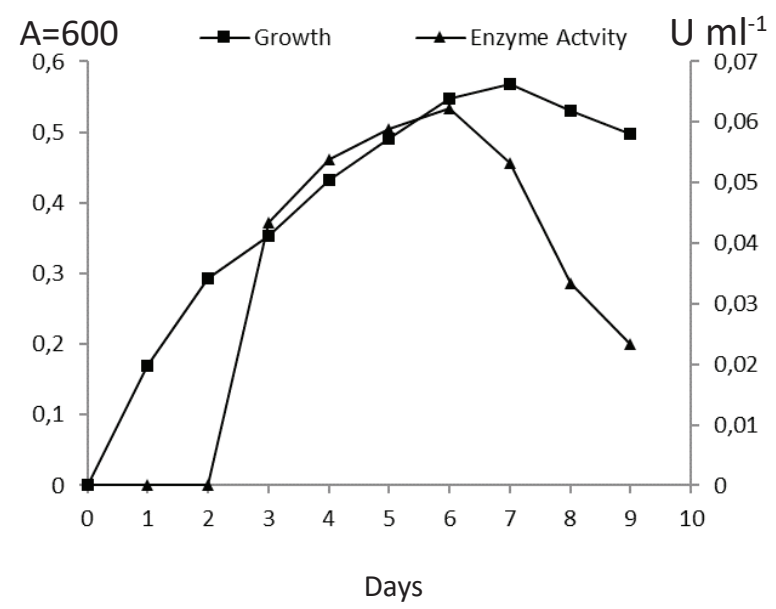

Figure 2. Maximum protease activity of $H$. morrhuae on the sixth day of growth

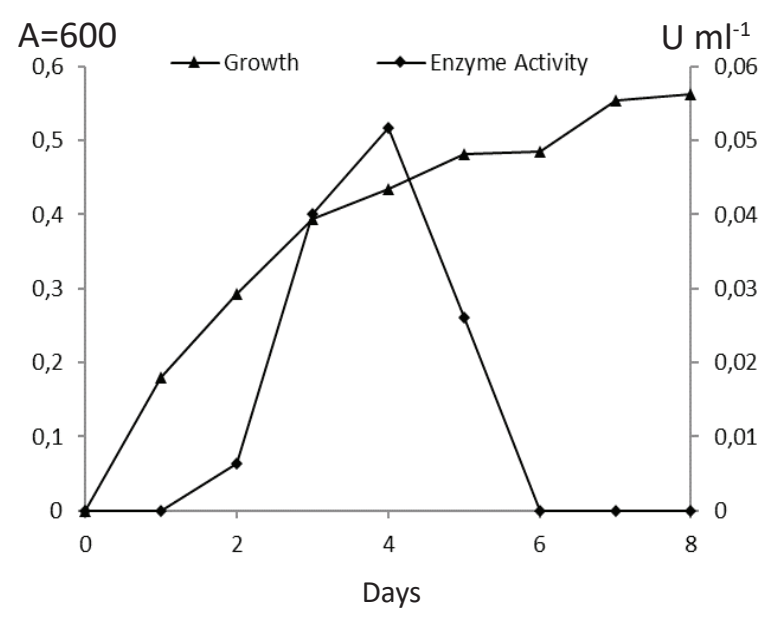

Figure 3. Maximum protease activity of $N$. pallidum on the fourth day of growth

The effect of $\mathrm{pH}$ on protease activity of Halococcus morrhuae and Natrinema pallidum was determined in the presence of $2 \mathrm{M} \mathrm{NaCl}$. Halococcus morrhuae enzyme exhibited significant activity in the $\mathrm{pH}$ range of 5.5-9.5 and the maximum activity value at $\mathrm{pH} 9.5$ was defined as $0.075 \mathrm{U} / \mathrm{ml}$. No activity could be determined at $\mathrm{pH} 5.0$ and 10.5 (Figure 4). The enzyme of Natrinema pallidum showed considerable activity in the $\mathrm{pH}$ range of 5.0-10.0 and reached the highest value at $\mathrm{pH} 9.0(0,063 \mathrm{U} \backslash \mathrm{mL})$. The activity was observed at $\mathrm{pH} 10.5$ as $0.023 \mathrm{U \backslash}$ $\mathrm{mL}$ but no activity was observed at $\mathrm{pH} 11.0$ (Figure 5).

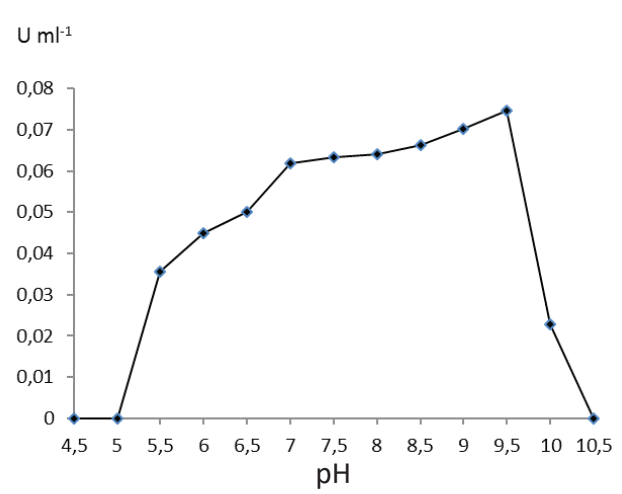

Figure 4. Effect of $\mathrm{pH}$ on extracellular protease activity of $\mathrm{H}$. morrhuae

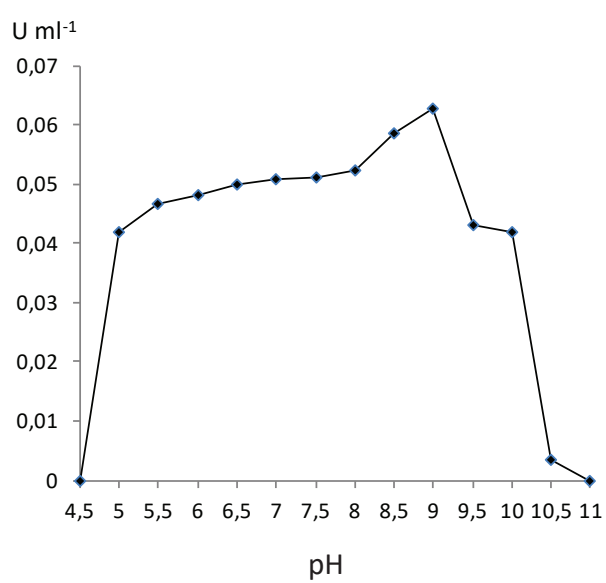

Figure 5. Effect of $\mathrm{pH}$ on extracellular protease activity of N. pallidum

For both isolates, it was found that $2 \mathrm{M} \mathrm{NaCl}$ was optimum concentration for the highest enzyme activity. However $H$. morrhuae and $N$. pallidum isolates were found to exhibit protease activity at 1.0$4.5 \mathrm{M} \mathrm{NaCl}$ and $1.0-3.0 \mathrm{M} \mathrm{NaCl}$, respectively (Figures 6 and 7). 


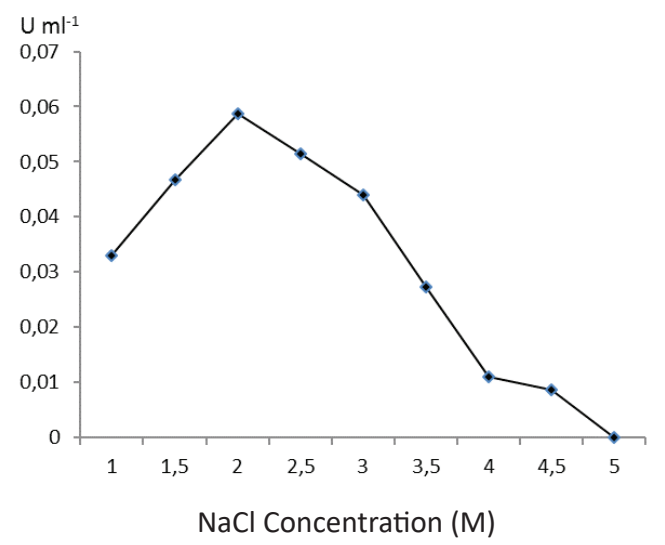

Figure 6. Effect of $\mathrm{NaCl}$ concentration on extracellular protease activity of H. morrhuae

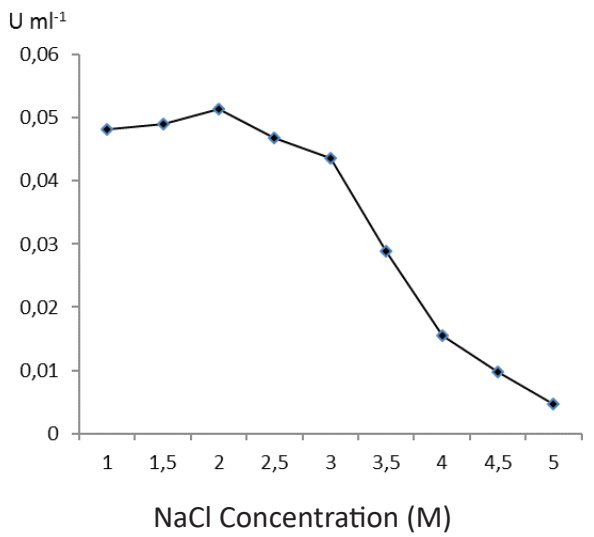

Figure 7. Effect of $\mathrm{NaCl}$ concentration on extracellular protease activity of N. pallidum

The effect of temperature on the protease activity of $H$. morrhuae and $N$. pallidum isolates was shown in Figures 8 and 9 respectively. While the optimum temperature for the enzymatic activity of $H$. morrhuae was found to be $50^{\circ} \mathrm{C}$, the optimum temperature for enzyme activity of $N$. pallidum was determined as $40^{\circ} \mathrm{C}$. On the other hand, it was found that protease activity was to be at a wide temperature range of $30-70^{\circ} \mathrm{C}$ for $\mathrm{H}$. morrhuae, $4-75^{\circ} \mathrm{C}$ for N. pallidum (Figures 8 and 9).

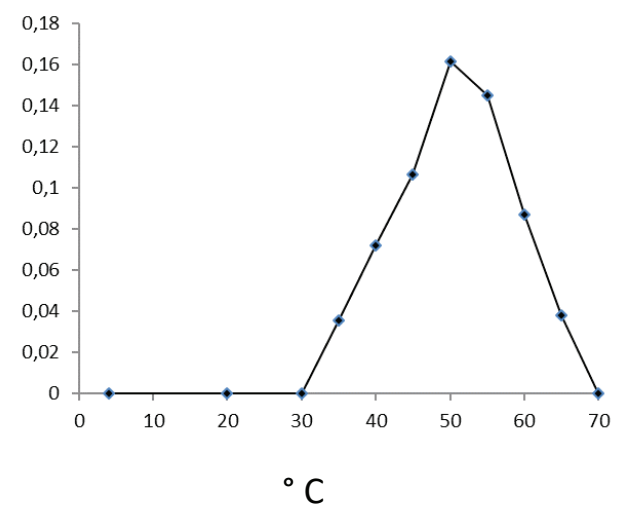

Figure 8. Effect of temperature on extracellular protease activity of $\mathrm{H}$. morrhuae

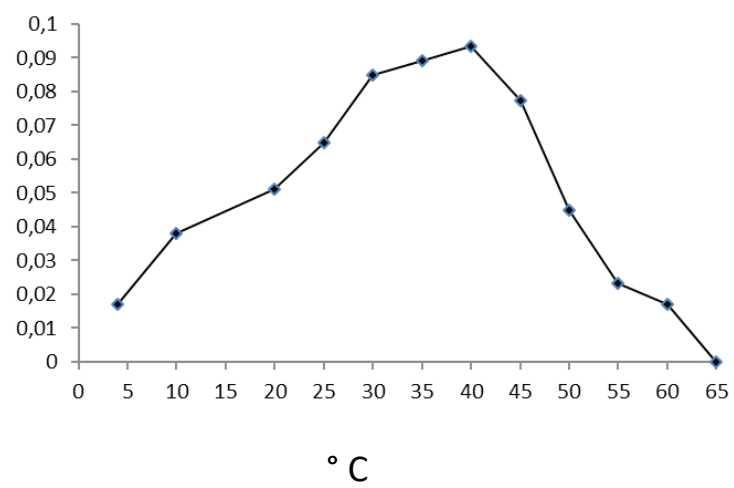

Figure 9. Effect of temperature on extracellular protease activity of N. pallidum

Accordingly, the obtained values for maximum extracellular protease activity of $H$. morrhuae and $N$. pallidum were determined as $50^{\circ} \mathrm{C}, 2 \mathrm{M} \mathrm{NaCl}, \mathrm{pH} 9.5$ and $40^{\circ} \mathrm{C}, 2 \mathrm{M} \mathrm{NaCl}$, $\mathrm{pH}$ 9.0, respectively.

Capiralla et al. [18] reported that optimum $\mathrm{pH}$ value for extracellular serine protease enzyme of Halobacterium halobium S9 was 8.0. Gimenez et al. [19] showed that the extracellular protease enzyme which isolated from Natrialba magadii exhibited an optimum activity between $\mathrm{pH}$ 8.0-10.0. We can say that our findings are similar to the findings obtained by the researchers in terms of $\mathrm{pH}$ value. Vijayanand et al. [14] reported that protease activity did not occur at a value below $\mathrm{pH} 5.0$ by Halobacterium sp. Js1. However, N. pallidum 153 exhibited protease activity between 
pH 4.5 -5 in our study. Kamekura et al. [20, 21] studied about Natrialba asiatica and their extracellular serine alkaline protease enzyme activity. Their results showed that maximum enzymatic reaction was at 1.3 $\mathrm{M} \mathrm{NaCl}$ concentration. On the contrary, for both isolates, it was found that $2 \mathrm{M} \mathrm{NaCl}$ was optimum concentration for the maximum enzyme activity, in our study. Temperature is one of the most important parameters for enzyme activities. Studies to determine the optimum temperature revealed that the protease showed a maximum activity at 40 and $50^{\circ} \mathrm{C}$. It could be said that our research findings in terms of temperature values were similar with the findings of these investigations. On the other hand, present studies show that most halophilic microorganisms did not exhibit enzyme activity at low temperature $[22,23,15]$. In contrast, it was found that protease activity was to be at a wide temperature range of 30$70^{\circ} \mathrm{C}$ for H. morrhuae, $4-75^{\circ} \mathrm{C}$ for N. pallidum, in our study.

\section{CONCLUSIONS}

In the study, firstly the haloarchaea were isolated from salted raw hide. The isolates were screened for production of protease enzyme and two isolates which have extracellular protease activity were selected. The halophilic archaea isolates were identified by using Gram staining method, antibiotic sensitivity tests and $16 \mathrm{~S}$ rRNA sequence analysis. It was determined that both isolates were Gram negative and susceptible to novobiocin and bacitracin antibiotics. According to the 16S rRNA molecular identification results, isolate 1 and isolate 2 identified as Halococcus morrhuae JCM 8876 and Natrinema pallidum 153 with 99\% sequence similarities, respectively. Secondly, protease activity conditions of the two extreme halophilic archaea were quantitatively determined. According to the research findings, the enzyme of Halococcus morrhuae and Natrinema pallidum exhibited activity in the $\mathrm{pH}$ range of 5.5-9.5 and 5.010.0 , at $1.0-4.5 \mathrm{M} \mathrm{NaCl}$ and $1.0-3.0 \mathrm{M} \mathrm{NaCl}$ concentrations, at a wide temperature range $30-70^{\circ} \mathrm{C}$ and $4-75^{\circ} \mathrm{C}$ respectively. Extremely halophilic archaea with proteolytic enzyme activities may cause major quality problems not only on the raw material but also the final leather. If archaea causing damage to the hide and skin by proteolytic activities were identified, target-specific antiarchaeal substances can be used to control them. Thus, the problems on the salted raw hide and skin can be solved. On the other hand, the obtained values for maximum extracellular protease activity of $H$. morrhuae and $N$. pallidum were determined as $50^{\circ} \mathrm{C}$, $2 \mathrm{M} \mathrm{NaCl}, \mathrm{pH} 9.5$ and $40^{\circ} \mathrm{C}, 2 \mathrm{M} \mathrm{NaCl}, \mathrm{pH} 9.0$, respectively. Finally, this study also showed that two different archaea isolated from salted raw hide can be evaluated in a wide variety of areas of the industry by further investigations.

\section{REFERENCES}

1. Madigan, M.T., Martinko, J.M., Brock Biology of Microorganisms, 11th Ed., Prentice Hall, International Inc, San Francisco, 2010, 5.

2. Woese, C.R., Fox, G.E., Phylogenetic Structure of The Prokaryotic Domain: The Primary Kingdoms. Proceedings of the National Academy of Sciences, 1977, 74, 11, 5088-5090.

3. Rampelotto, P.H., Extremophiles and Extreme Environments, Life, 2013, 3, 482-485, https://doi.org/10.3390/ life3030482.

4. DasSarma, S., Extreme Halophiles Are Models for Astrobiology, Microbe, 2006, 1, 3, 120-126, https://doi.org/10.1128/ microbe.1.120.1.

5. Akolkar, A.V., Deshpande, G.M., Raval, K.N., Durai, D., Nerurkar, A.S., Desai, A.J., Organic Solvent Tolerance of Halobacterium sp. sp1(1) and Its Extracellular Protease, J Basic Microbiol, 
2008, 48, 1-5, https://doi.org/10.1002/ jobm. 200800012.

6. Margesin, R., Schinner, F., Potential of Halotolerant and Halophilic Microorganisms for Biotechnology, Extremophiles, 2001, 5, 73-83.

7. Adams, M.W.W., Kelly, R.M., Enzymes in Extreme Environments, Chem Eng News, 1995, 73, 32-42, https://doi.org/10.1021/ cen-v073n051.p032.

8. Banat, I.M., Makkar R..S., Cameotra, S.S., Potential Commercial Applications of Microbial Surfactans, Appl Microbiol Biotechnol, 2000, 53, 495-508.

9. Rao, M.B., Tanksale, A.M., Gathe, M.S., Deshpande, V.V., Molecular and Biotechnological Aspects of Microbial Proteases, Microbiol Mol Biol Rev, 1998, 62, 3, 597-635.

10. Dussault, H.P., An Improved Technique for Staining Red Halophilic Bacteria, J Bacteriol, 1955, 70, 484-485.

11. Dyall-Smith, M., The Halohandbook Protocols for Haloarchaeal Genetics, Version 7, 2008, 7, 144.

12. Bilgi, S.T., Meriçli Yapici, B., Karaboz, i., Determination of Hydrolytic Enzyme Capabilities of Halophilic Archaea Isolated from Hides and Skins and Their Phenotypic and Phylogenetic Identification, J Am Leather Chem As, 2015, 110, 2, 33-42.

13. Ibrahim, A.S.S, Al-Salamah, A.A., Optimization of Media and Cultivation Conditions for Alkaline Protease Production by Alkaliphilic Bacillus Halodurans, Res J Microbiol, 2009, 4, 7, 251-259.

14. Vijayanand, S., Hemapriya, J., Selvin, J., Kiran, S., Production and Optimization of Haloalkaliphilic Protease by an Extremophile-Halobacterium sp. js1, Isolated from Thalassohaline Environment, Global J Biotechnol Biochem, 2010, 5, 1, 44-49.
15. Karadzic, I., Masui, A., Fujiwara, N., Purification and Characterization of a Protease from Pseudomonas aeruginosa Grown in Cutting Oil, J Biosci Bioeng, 2004, 98, 3, 145-152, https://doi. org/10.1016/S1389-1723(04)00258-0.

16. Uratani, J.M., Kumaraswamy, R., Rodríguez, J., A Systematic Strain Selection Aproach for Halotolerant and Halophilic Bioprocess Development: A Review, Extremophiles, 2014, 18, 4, 629639, https://doi.org/10.1007/s00792014-0659-4.

17. Henroette, C., Zinebi, S., Aumaitre, M.F., Petitdemange, E., Petitdemange, H., Protease and Lipase Production by a Strain of Serratia marcescens, J Ind Microbiol, 1993, 12, 129-135.

18. Capiralla, H., Hiroi, T., Hirokawa, T., Maeda, S., Purification and Characterization of a Hydrophobic Amino Acid Specific Endopeptidase From Halobacterium halobium S9 with Potential Application in Debittering of Protein Hydrolysates, Process Biochem, 2002, 38, 4, 571579, https://doi.org/10.1016/S00329592(02)00180-2.

19. Gimenez, M.I., Studdert, C.A., Sanchez, J.J. De Castro R.E., Extracellular Protease of Natrialba magadii; Purification and Biochemical Characterization, Extremophiles, 2000, 4, 181-188.

20. Kamekura, M., Seno, Y.A., Halophilic Extracellular Protease from a Halophilic Archaebacterium 172 P1, Biochem Cell Biol, 1990, 68, 352-359, https://doi. org/10.1139/o90-048.

21. Kamekura, M., Dyall-Smith, M.L., Taxonomy of the Family Halobacteriaceae and the Description of Two New Genera Halorubrobacterium and Natrialba, J Gen Appl Microbiol, 1995, 41, 333-350.

22. Huang, Q., Peng, Y., Li, X., Wang, H., Zhang, Y., Purification and Characterization of 
an Extracellular Alkaline Serine Protease with Dehairing Function from Bacillus pumilus, Curr Microbiol, 2003, 46, 169173, https://doi.org/10.1007/s00284002-3850-2.

23. Gomes, J., Stetiner, W., The Biocatalytic Potential of Extremophiles and Extremozymes, Food Technol Biotechnol, 2004, 42, 223-235.
(C) 2017 by the author(s). Published by INCDTP-ICPI, Bucharest, RO. This is an open access article distributed under the terms and conditions of the Creative Commons Attribution license (http://creativecommons. org/licenses/by/4.0/). 